\title{
Behov for en geologisk kanon - vulkanske intrusioner og klipper
}

Af professor emeritus Henning Sørensen, Geologisk Institut, København

Der tales meget om kanoner i denne tid. Der er opstillet kanoner for litteraturundervisningen i skoler og gymnasier, og flere er på vej. Jeg skal i det følgende vise, at også geologien kunne være tjent med at få en sådan.

Geologi opfattes stadig som et traditionelt naturhistorisk fag i gammeldags forstand, dvs. noget som er lige ud ad landevejen. Men faget har været igennem en rivende udvikling og er ikke længere helt så enkelt at stifte bekendtskab med, som mange forventer. Desuden har geologi ligesom andre videnskaber et fagsprog. Selv om formidlere af geologisk stof gør sig umage med at skrive så letforståeligt som muligt, kan fagord ikke undgås, man kan jo ikke forklare alting fra grunden hver gang. Det stiller også krav til læserne.

Mangel på almen dansk geofremstilling Det danske geologiske fagsprog har en lang tradition. Her skal specielt peges på betydningen af, at vi har haft gode bøger om geologiens hovedtræk. Især skal nævnes Niels Viggo Ussings Kortfattet Larebog $i$ den almindelige Geologi fra 1901, sjette og sidste udgave i 1942, og dens afløser, Arne Noe-Nygaards Geologi - Processer og Materialer fra 1954, fjerde udgave i 1967.

Det var let at slå op i disse bøger og se, hvad forskellige geologiske fænomener kaldes. Desværre er traditionen med en dansk produceret almen fremstilling af geologien ikke videreført. Men det skal nævnes, at der i Den Store Danske Encyklopcedi (SDE) er lagt megen vægt på at dække alle hovedområder af geologien. De fleste vigtige fagudtryk er forklaret dér.

Geologiens fagsprog er koordineret på internationalt plan. Jeg har i artikler i GeologiskNyt $(4 / 02)$ og $\operatorname{Varv}(2002,4)$ fortalt om bestræbelserne på at etablere et internationalt anvendeligt system for magmabjergarterne. Tilsvarende initiativer er taget inden for andre grene af geologien.

\section{Problemet "rock"}

Manglen på en moderne, let tilgængelig, dansk fremstilling af geologien koblet med den ovennævite opfattelse af, at geologi er noget lige ud ad landevejen, har sat sine spor

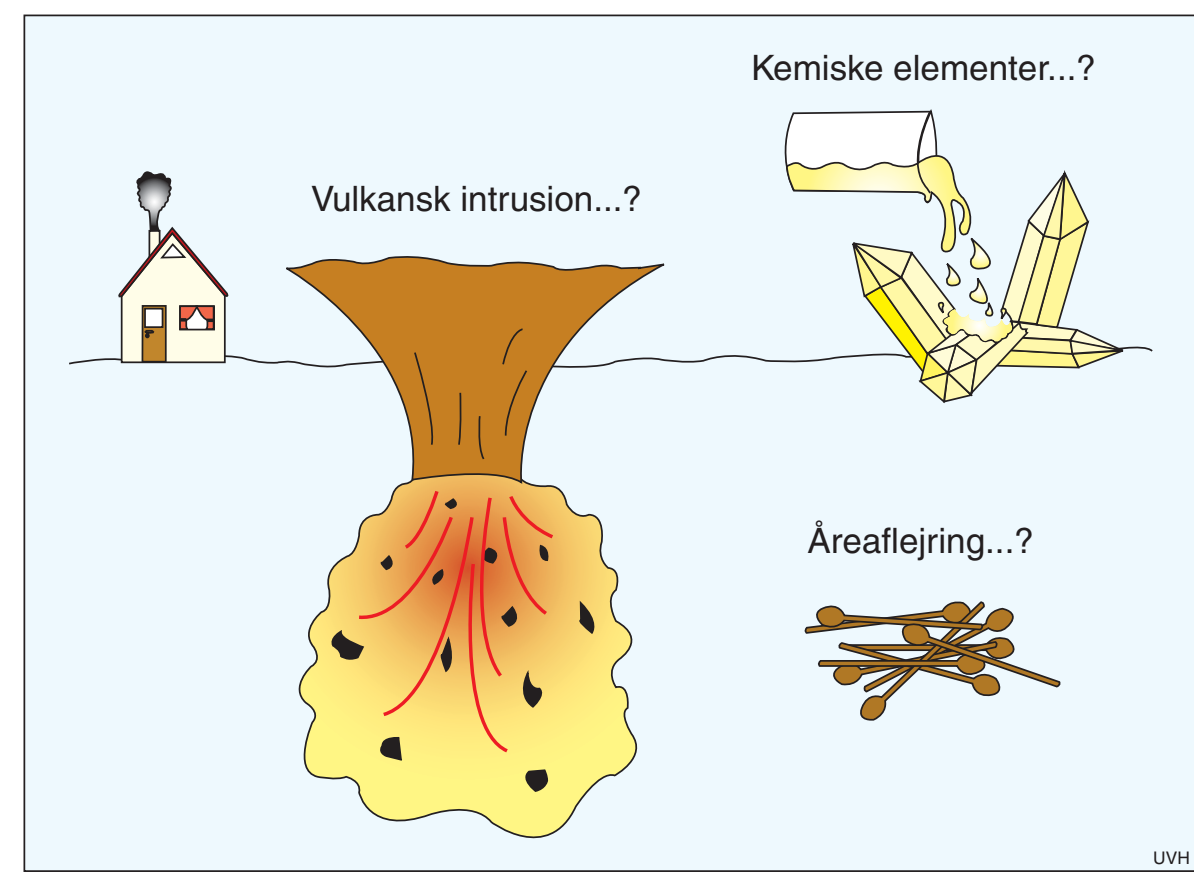

i de fremmedsprogede geologiske værker, som fra tid til anden udkommer i dansk oversættelse. Det gælder også oversatte artikler i dagblade og de populærvidenskabelige tidsskrifter. Det synes, som om hvem som helst kan blive sat til at oversætte geologiske tekster, og at der er mangelfuld kontrol med oversættelserne.

Et godt eksempel på et oversætterproblem er det engelske ord rock. Det bliver ofte oversat til klippe, selv hvor der er tale om forhold dybt nede i Jorden. Den rigtige oversættelse er i sådanne tilfælde bjergart. Slår man op i Gyldendals røde EngelskDansk ordbog, står der rock: klippe, bjerg art. Det er nemmest at vælge det, der står først, når man ikke ved bedre, men der er jo forskel på en landskabsform og et materiale. Begreber som grundstof, metal, malm og bjergart volder i det hele taget oversætterne store problemer. Det vil jeg illustrere med eksempler fra den nyligt udkomne bog Jorden - Illustreret Opslagsvaerk (Forlaget Aktium), her omtalt som JIO. Den er anmeldt i GeologiskNyt 5/04. Jeg er enig med anmelderen i, at det er et pragtværk, men at oversættelsen er kritisabel. Der er så mange oversætterbommerter i bogens geologiske kapitler, at en gennemgang nemt kunne fylde et helt nummer af GeologiskNyt.

Jeg skal begrænse mig til nogle få karakteristiske eksempler inden for den hårde geologi.

\section{Udpluk fra bogen Jorden}

$\mathrm{JIO}$ oplyser, at kun 30 af de mere end 4.000 kendte mineraler forekommer på Jordens overflade, de kaldes de stendannende mineraler. Hvor kender man så de andre ca. 3.970 mineraler fra? Ordet sten er en ny variation over temaet rock og anvendes $i$ bogens tekst næsten konsekvent i stedet for det korrekte fagudtryk bjergart. I værkets ordliste er det lige omvendt, begrebet bjergart anvendes i mange opslag på mere eller mindre korrekt måde. Opslaget bjergart $\mathrm{i}$ ordlisten lyder fx: "Ethvert solidt materiale bestående af ét eller flere mineraler, og som findes naturligt på Jorden og andre planeter". Engelsk solid er oversat ordret, det korrekte ord er fast. For god ordens skyld, jeg citerer fra SDE: "Sten: hårde stykker af bjergarter, der er større end grus og mindre end blokke". Dvs. sten er brudstykker af bjergarter og yderligere betegnelsen for en kornstørrelseskategori. Bjergart er i SDE defineret som "de produkter, der dannes af de geologiske processer...., dvs. sammenhobninger eller sammenvoksninger af korn af et eller flere mineraler". (I JIO tales om sammenvævninger af mineraler).

I JIO's ordliste defineres grundstof som et "kemisk grundelement i naturen". I teksten bruges i nogle kapitler grundstof på korrekt måde, $i$ andre er der oversat direkte fra det engelske ord for grundstof, element, til dansk element. I kapitlet om mineraler har 
oversætterne fået rodet det hele sammen.

Det indledes: "Mineraler er de naturlige byggesten i sten, klipper og planeten Jorden samt alle universets faste elementer.... Nogle mineraler er.... amorfe faste elementer.....". Lidt længere nede: "de enkelte mineraler kan kendes på unikke kombinationer af kemiske elementer...". Element bruges i flere betydninger og ordet grundstof er betegnelse for "en gruppe på ca. 20 elementer...(der)... omfatter mineraler som fx guld og platin...", den undergruppe af mineraler, som består af "rene" grundstoffer, dvs. at ordet grundstof fejlagtigt opfattes som et mineralogisk begreb.

I JIO's udmærkede illustrationer bruges betegnelsen magma, men magmatisk er erstattet af vulkansk i såvel teksten som i de fordanskede dele af illustrationerne, hvor begrebet vulkanske sten anvendes som betegnelse for magmabjergarter. Her må oversætteren være gået galt af det engelske ord igneous. I Gyldendals røde ordbog står: igneous: vulkansk; igneous rock: magmatisk bjergart, magmabjergart... Oversætteren har også her valgt det ord, der står først i ordbogen. Og igen er der divergenser mellem teksten og ordlisten. I sidstnævnte skelnes i opslaget vulkansk bjergart korrekt mellem ekstrusive (vulkanske) og intrusive (plutoniske) bjergarter, men der sluttes ukorrekt med "en intrusiv vulkansk bjergart kaldes en vulkansk intrusion”. Ordet vulkansk knytter sig til processer, som foregår på og nær jordoverfladen. Anvendelsen af betegnelsen vulkanske intrusioner om forhold dybt nede i Jorden er noget gedigent sludder, det samme er sedimentcere sten som betegnelse for sedimentære bjergarter. Granit er blevet til en vulkansk sten og pegmatit til en plutonisk vulkansk bjergart, hvilket om muligt er endnu mere sludder, selv om det er en formildende omstændighed, at der står bjergart og ikke sten.

Vi slipper ikke for anvendelsen af ordet klippe om processer, der foregår dybt nede i skorpen eller kappen, magma betegnes $\mathrm{fx}$ som smeltet klippe, der kommer inde fra Jorden. På side 195 siges under overskriften krystalstruktur, at alle vulkanske klippearter dannes ved nedkøling af magma, ordet krystalstruktur synes at henvise til kornstørrelse, men krystalstruktur er jo noget helt andet, ordet er, så vidt jeg har konstateret, ikke brugt dér, hvor det hører hjemme, nemlig i omtalen af krystaller.

Til slut nogle eksempler på veritable bommerter. På side 63 skrives under overskriften åreaflejringer: "Mineralaflejringer, hvorfra værdifulde metaller kan udvindes, kaldes årer. Markederne afgør om en naturlig koncentration af et mineral kan kaldes en åre." Her er engelsk ore tydeligvis blevet til åre, og deposit til aflejring. De korrekte ord er malm og forekomst. I ordlisten er ore korrekt oversat til malm. Åre er jo noget helt andet.

På side 195 står, at basaltgange opstår ved, at lava flyder ned i sprækker, i sandhed den omvendte verden. Det samme gælder udsagnet om, at basaltmagma er mindre tæt end granitmagma. Engelsk density er næsten konsekvent oversat som tæthed og i mindre grad som massefylde, hvilket ikke fremmer klarheden. På side 56 fortælles om jordskælvsbølger, som har været igennem Jordens kerne, at de passerer gennem en såkaldt skyggezone. Illustrationen på side 57 viser at det ikke er tilfældet.

\section{Om bogen Jorden}

Bogen er på 520 store sider og dækker næsten alt om Jorden, altså meget andet end geologi. Den er skabt af det anerkendte Smithsonian Institut og museum i Washington D.C. og er forsynet med et fremragende illustrationsmateriale og mængder af eksempler. Den engelske tekst er så ordret oversat, at det er let at se, at den er af høj kvalitet. Det samme kan ikke siges om oversættelsen af de geologiske afsnit, der ud over fejl, som de her påviste, er meget kluntet og skrevet i et dårligt dansk sprog med inkonsekvent anvendelse af begreber.

Hvad vil den almindelige læser uden forudsætninger få ud af en bog som denne? Den er dejlig at bladre i og giver mulighed for at få noget at vide om næsten utallige forhold vedrørende vor Jord. Men den er ikke let at læse. Læseren med baggrundsviden vil kunne få stor glæde af illustratio-

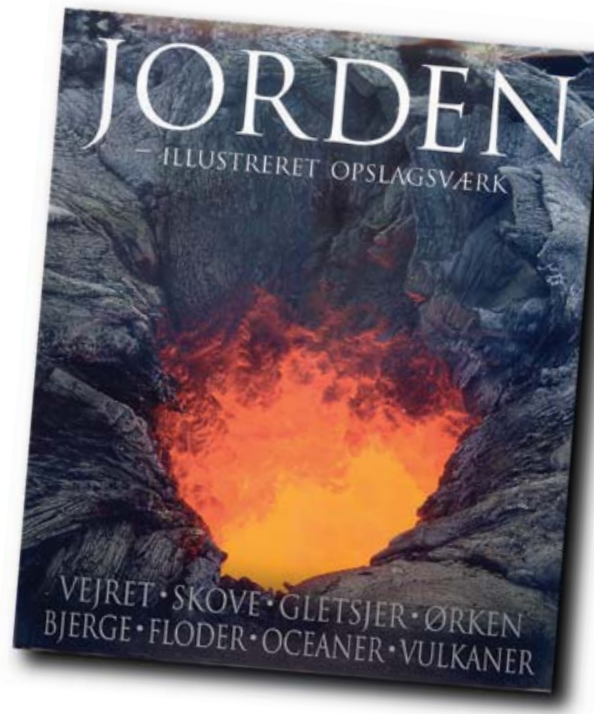

nerne og de mange eksempler på vulkaner, jordskælv, osv., men vil krumme tæer ved at læse teksten.

Gør det noget, at bjergarter omtales som sten, og at den danske udgave benytter betegnelser, der ikke er i overensstemmelse med det fagsprog, som er udviklet $i$ løbet af mere end hundrede år, og som anvendes af både professionelle og amatører? En fagterminologi som i stort omfang er fælles for de nordiske lande. Ja, mener jeg, et fag er bl.a. karakteriseret af dets fagsprog, det er vigtigt at betegnelserne er entydige og præcise.

\section{En geologisk kanon}

Dette fører frem til behovet for en geologisk kanon, som samler fagterminologien med links til begrebernes navne på engelsk og evt. andre sprog. Der savnes en dansksproget Almen Geologi og en let tilgængelig kilde til oplysninger om $\mathrm{fx}$ den danske terminologi i forhold til andre sprogs terminologi. Det kunne løses via Internettet.

Det fører videre frem til, at det bør høre med til almindelig dannelse at kende hovedtræk af geologien. Det er den, der beskriver og studerer den Jord, vi lever på, og hvis ressourcer vor tilværelse er baseret på. Men trods dette indgår geologi næsten ikke i 
skole- og gymnasieuddannelserne og inddrages kun lidt i mediernes behandling af Jordens forhold. I USA er situationen meget lig den danske, dvs. at generation efter generation af elever forlader uddannelsessystemet med begrænset eller ingen viden om den planet, de bor på. Dermed afskæres de fra at forstå og tage kvalificeret stilling til aktuelle spørgsmål som klimaudvikling, geologiske katastrofer, ressourceforhold, osv. Derfor foreslår amerikanske geologer, at der arbejdes på at skabe geological literacy, hvilket omsat til dansk betyder en geologisk almendannelse baseret på viden om de mest basale forhold inden for geologien. Tilsvarende behøves inden for andre videnskaber. Man kunne begynde med at genskabe det hedengangne filosofikum som et alment videnskabskursus over hovedtræk af naturvidenskaberne. Den netop offentliggjorte Pisaundersøgelse af europæiske skolebørns viden om bl.a. naturvidenskab viser, at behovet for en indsats ikke er mindre inden for skolesystemet. Men tingene hænger sammen, skoleuddannelsernes kvalitet afhænger af lærernes dygtighed og viden. Det er et

\section{Kort nyt}

\section{Dansk Normalnul er forældet}

Den 1. januar 2005 vil det gamle Dansk Normalnul (forkortet DNN) være forældet, idet det skiftes ud med det nye kotesystem DVR90. Der er ikke blot tale om en navneændring, for den indebærer i virkeligheden en overgang til opdaterede koter. Mange ældre koter er nemlig forkerte, og det skyldes ikke forkerte opmålinger, men at landet vipper på en sådan måde, at Nordjylland stiger, og resten af landet synker.

I den forbindelse har Kort og Matrikelstyrelsen udgivet en lille pjece, der kan hentes på styrelsens hjemmeside www.kms.dk). Her er der bl.a. angivet, hvor meget overgangen til de nye højdeniveauer betyder forskellige steder i landet. Forskellen er nemlig ikke ens over hele landet, men varierer mellem $+2 \mathrm{og}-14 \mathrm{~cm}$.

\section{Ikke en bombe, men en meteorit}

Efter flere terrorvarsler var de indonesiske myndigheder i højeste alarmberedskab, især op til julen, hvor flere lande havde opfordret deres landsmænd til at undgå bestemte hoteller. Derfor var mange i og omkring hovedstaden Jakarta også sikre på, at der var yderligere argument for at forbedre den almene viden om geologi såvel som om andre videnskaber.

GeologiskNyt har i de seneste numre behandlet geologiens status i Danmark. Det er konstateret, at den kunne være ikke så lidt bedre. Det er først og fremmest op til faget selv at forbedre disse forhold, forslag til tiltag er nævnt i det ovenstående. I nr.5/04 påpeger Carsten R. Kjaer og Jørgen Dahlgaard at der, til trods for eksistensen af hele fire geologiske tidsskrifter i Danmark, ikke findes et eneste, som når uden for en snæver kreds af faggeologer og amatørgeologer. De peger også på, at det omgivende samfunds manglende interesse for geologi kan føres tilbage til en meget uheldig tradition for indadvendthed i den geologiske verden. Jeg er helt enig med dem i, at "denne uheldige tradition må ændres, hvis ikke faget fortsat skal friste en marginal tilværelse som det 'ukendte naturfag' i Danmark", og, jeg kan tilføje, at måtte se på at formidlingen af geologisk stof foregår på så ukvalificeret måde, som Jorden er et af flere eksempler på. Lad kanonen blive bragt i stilling! tale om en bombe, da de tidligt søndag morgen den 19. december blev vækket af et højt brag. Imidlertid viste det sig, at der var tale om en meteorit, der ved mødet med jordens atmosfære er blevet opvarmet så meget, at den eksploderede.

Ifølge øjenvidner slog meteoritten ned et sted i det vestlige Java, hovedøen i Indonesien; men det er indtil videre ikke lykkedes at bekræfte dette gennem fund. Det formodes derfor, at meteoritten er gået til ved eksplosionen.

$w w w . d p a . d e / E K$

\section{Fejl på bagsiden!}

I sidste nummer stod der fejlagtigt på bagsiden, at "Blue Pearl" er en plagioklas - det er fokert! "Blue Pearl" er det tekniske navn for en varietet af bjergarten larvikit fra Sydnorge. Feldspatten er ikke labrador, men en ternær alkalifeldspat (dvs. den lugter af plagioklas), og det er ikke albittvillinglameller, som er årsag til farvespillet. Vi beklager fejlen! Redaktionen 